\title{
Quality of Life -- Lifelong Education Platform
}

\author{
Ivica Radovanović ${ }^{1, *}$, Dragana Bogavac ${ }^{1}$, Zorica Cvetanović1 ${ }^{1}$ Jasmina Kovačević $^{2}$ \\ ${ }^{1}$ Faculty of Teacher Education, University of Belgrade, Serbia \\ ${ }^{2}$ Faculty of Special Education and Rehabilitation, University of Belgrade, Serbia
}

Copyright $\bigcirc 2017$ by authors, all rights reserved. Authors agree that this article remains permanently open access under the terms of the Creative Commons Attribution License 4.0 International License

\begin{abstract}
The aim of the research was to examine the quality of adolescents' lives in order to assess how much it serves the purpose of effective lifelong education. The sample consisted of 220 pupils from the first to the fourth grade of secondary school on the territory of Serbia. The quality of life of the respondents was assessed by means of a questionnaire on the quality of life - PedsQL ${ }^{\mathrm{TM}}$. The following was examined: Emotional, Social and Physical functioning. The results of the research showed a high level of life quality related to the aspects of physical functioning and social functioning, while emotional functioning is marked as a dimension with a lower degree of quality. Factor analysis revealed six relatively independent factors. The results indicate that the quality of students' life is still not at an enviable level and that it is important to work systematically in this field.
\end{abstract}

Keywords Quality of Life, Social Functioning, Emotional Functioning, Physical Functioning, Lifelong Education

\section{Introduction}

Lifelong education involves a supportive environment. Likewise, quality of life is reflected in the creation, maintenance and improvement (physical, psychological and social aspect, health and safety) of the work environment (Chiavenato, 2009: 334). Such an environment implies primarily a motivated, productive and innovative participant (Limongi-França, 2007: 156).

Quality of life can be analysed from several perspectives (Limongi-França, 2012: 30), so we are bound to encounter numerous definitions and operationalisations of this concept in theoretical concepts and research (Marić, 2012).

According to the definition of the World Health Organisation, quality of life represents the state of complete physical, mental and social well-being and it is a multidimensional concept involving both physical and psychosocial aspects (Jovanović, 2013). Quality of life is part of individual's mental state, a reflection of his/her development, social and physical environment and position in the said environment (WHOQOL Group, 1998; Murphy et al, 2000). Assessing one's quality of life is a basic condition and the first step in creating an improvement strategy which involves identifying obstacles, designing action plans and undertaking the most adequate activities to improve the quality of life (Damnjanović, 2012).

Quality of life occupies a significant position in sociology, psychology, medicine (Fayers and Machin, 2007; Guyatt et al, 1991), but in pedagogy as well (Slavnić et al., 2015). From the sociological standpoint, the concept of quality indicates satisfaction with one's life, level of functioning in the environment, while simultaneously enabling monitoring of the availability of social protection. From the psychological aspect, quality of life provides information on the person's feelings and interactions with others. In medicine, quality of life is a relatively new concept the purpose of which is not only prevention, alleviation of symptoms of various illnesses and their consequences, but a struggle for a more comprehensive, wholesome and better life (Damnjanović, 2012).

From the pedagogical aspect, quality of life refers to levels of education and a well-established need for lifelong education and improvement of acquired competencies. Numerous studies confirm that one's quality of life is greatly influenced by the level of education attained, in addition to satisfaction with oneself and relationships with others, material situation, living conditions, work and leisure time (Ryff et al., 1999; Arsovski, 2007; Milošević, 2009). Lack of competencies and skills restricts access to quality jobs and increases the risk of social exclusion and poverty, and it can also be an obstacle to full participation in social activities. Responsibility in the field of education (lifelong education) as a category causes stress and exhaustion which implies disturbance in the quality of work and in turn, quality of life of an individual (Assunção \& Oliveira, 2009; 361). We should also mention the organisational aspect as a benefit of the quality of life. 
Investing in quality of life is important, but it must not be based solely on the application of new technologies, which certainly contribute to individual's work potential, instead, its ultimate purpose should be the quality of the society as a whole (Limongi-França, 2012: 42). It is crucial to understand this relation as reciprocal, i.e. social context should be involved in a permanent analytical process focused on different dimensions of quality of life.

\section{Method}

The goal of this research was to examine the quality of life of adolescents in order to assess its contribution to an efficient lifelong education. Research questions were designed to evaluate three domains of quality of life: emotional functioning, social functioning and physical health functioning.

The basic research method was the survey method. We also used the method of theoretical analysis to complement the basic method.

The sample comprised 220 students of secondary school from the first to the fourth grade. Table 1 shows that the number of students from the first (23.6\%), second (24.5\%), third $(26.4 \%)$ and fourth $(25.5 \%)$ grade is pretty much even.

Table 1. Sample structure by respondents' grade

\begin{tabular}{ccc}
\hline Grade & $\mathrm{f}$ & $\%$ \\
\hline 1 st & 52 & 23,6 \\
2nd & 54 & 24,5 \\
3rd & 58 & 26,4 \\
4 th & 56 & 25,5 \\
In total & 220 & 100,0 \\
\hline
\end{tabular}

An important factor in this research was to determine the environment in which students live, in other words, whether they live in urban or rural areas. The percent of students who live in urban areas was slightly higher $(62.7 \%)$ than the percent of students who live in rural areas $(37.3 \%)$, which can be seen in Table 2 .

Table 2. Sample structure by students' place of residence

\begin{tabular}{ccc}
\hline Type of settlement & $\mathrm{f}$ & $\%$ \\
\hline City & 138 & 62,7 \\
Village & 82 & 37,3 \\
In total & 220 & 100,0 \\
\hline
\end{tabular}

Another important indicator of the sample structure was student's gender. The sample was more or less uniform in terms of gender, i.e. the percent of boys $(45.5 \%)$ and girls $(54.5 \%)$ participating in the research, which is shown in Table 3.
Table 3. Sample structure by students' gender

\begin{tabular}{ccc}
\hline Gender & $\mathrm{f}$ & $\%$ \\
\hline Male & 100 & 45,5 \\
Female & 120 & 54.5 \\
In total & 220 & 100,0 \\
\hline
\end{tabular}

The research was conducted in the Republic of Serbia. Quality of life of respondents was assessed with a questionnaire on quality of life - PedsQL ${ }^{\mathrm{TM}}$. This is a generic questionnaire for assessing the quality of life (QOL) of children and adolescents between the ages of 8 and 18 . We used the following scales for research purposes: Emotional functioning (5 questions), Social functioning (5 questions) and Physical functioning (8 questions). The responses were ranked from 1 to 5 . Data were processed with statistics software package SPSS 21.0. We used the following statistical procedures: descriptive statistics, t-test, ANOVA and factor analysis.

\section{Findings}

Personal hygiene represents the lowest-ranking type of physical effort for students, with 1.24 points on the scale. Thus, $86.4 \%$ students responded that they never find showering or maintaining personal hygiene hard or bothersome. The second item, with 1.54 points on the scale, shows that long hikes are commonly not counted as an effort. $63.6 \%$ students responded that they never find it difficult to walk down several streets, whereas $19.9 \%$ said that it's almost never an effort. The item referring to running, with 1.97 points on the scale, shows that most respondents do not find this activity hard to perform. However, in addition to those who do not find running challenging at all (43.6\%) and those who commonly don't have troubles with running $(23.6 \%)$, there are students who sometimes find this activity exhausting (26.4\%). The next item shows whether students are able to perform everyday activities or not, with 2.08 points on the scale. Responses to the statement "I don't have enough strength" are divided between never (36.4\%), almost never (26.4\%) and sometimes $(31.8 \%)$. Two items with the same number of points, 2.19 , refer to heavy lifting and presence of pain. Heavy lifting is not an effort for about a third of students $(35.3 \%)$. When it comes to the seventh item, 34.5\% students claimed that they never experience pain, whereas $22.7 \%$ stated that they almost never experience pain. The eighth item refers to doing housework, with 2.21 points, and $40 \%$ of respondents said that they are never too tired to do housework, whereas $21.8 \%$ claimed that they are almost never too tired for housework. The average ranking on the physical functioning scale is 1.88 , which tells us that most responses are grouped around the $2^{\text {nd }}$ point on the scale almost never.

The scale of physical functioning contains 8 questions, responses are ranked from 1 to 5 , and the results are shown in Table 4. 
Table 4. Scale of physical functioning

\begin{tabular}{|c|c|c|c|c|c|c|}
\hline Item & Never & $\begin{array}{c}\text { Almost } \\
\text { never }\end{array}$ & Sometimes & Often & $\begin{array}{l}\text { Almost } \\
\text { always }\end{array}$ & Ranking \\
\hline \multirow{2}{*}{ It is hard for me to take showers or baths. } & 190 & 16 & 8 & 4 & 2 & \multirow{2}{*}{1,24} \\
\hline & $86,4 \%$ & $7,3 \%$ & $3,6 \%$ & $1,8 \%$ & $0,9 \%$ & \\
\hline \multirow{2}{*}{$\begin{array}{l}\text { It is hard for me to walk more than several } \\
\text { streets. }\end{array}$} & 144 & 42 & 30 & 0 & 4 & \multirow{2}{*}{1,54} \\
\hline & $65,5 \%$ & $19,1 \%$ & $13,6 \%$ & $0,0 \%$ & $1,8 \%$ & \\
\hline \multirow{2}{*}{$\begin{array}{l}\text { It is hard for me to play sports or engage in } \\
\text { any form of exercise. }\end{array}$} & 140 & 36 & 28 & 12 & 4 & \multirow{2}{*}{1,65} \\
\hline & $63,6 \%$ & $16,4 \%$ & $12,7 \%$ & $5,5 \%$ & $1,8 \%$ & \\
\hline \multirow{2}{*}{ It is hard for me to run. } & 96 & 52 & 58 & 10 & 4 & \multirow{2}{*}{1,97} \\
\hline & $43,6 \%$ & $23,6 \%$ & $26,4 \%$ & $4,5 \%$ & $1,8 \%$ & \\
\hline \multirow{2}{*}{ I don't have enough strength. } & 80 & 58 & 70 & 8 & 4 & \multirow{2}{*}{2,08} \\
\hline & $36,4 \%$ & $26,4 \%$ & $31,8 \%$ & $3,6 \%$ & $1,8 \%$ & \\
\hline \multirow{2}{*}{ It is hard for me to do any heavy lifting. } & 78 & 50 & 72 & 12 & 8 & \multirow{2}{*}{2,19} \\
\hline & $35,5 \%$ & $22,7 \%$ & $32,7 \%$ & $5,5 \%$ & $3,6 \%$ & \\
\hline \multirow{2}{*}{ I experience pain. } & 76 & 50 & 72 & 20 & 2 & \multirow{2}{*}{2,19} \\
\hline & $34,5 \%$ & $22,7 \%$ & $32,7 \%$ & $9,1 \%$ & $0,9 \%$ & \\
\hline \multirow{2}{*}{ It is hard for me to do the housework. } & 88 & 48 & 46 & 26 & 12 & \multirow{2}{*}{2,21} \\
\hline & $40,0 \%$ & $21,8 \%$ & $20,9 \%$ & $11,8 \%$ & $5,5 \%$ & \\
\hline
\end{tabular}

It was important to determine whether there are differences in physical functioning in relation to respondent's grade, which is shown in Table 5. Differences in attitudes between grades have been examined with a $\mathrm{t}$-test. You can see from the table that there is a statistically significant difference between grades $(\mathrm{p}=0,000)$.

Table 5. Physical functioning in relation to grade

\begin{tabular}{cccccc}
\hline Grade & $\mathrm{N}$ & Mean & df & $\mathrm{F}$ & $\mathrm{p}$ \\
\hline $1^{\text {st }}$ & 52 & 1,60 & & & \\
$2^{\text {nd }}$ & 54 & 2,14 & & & \\
$3^{\text {rd }}$ & 58 & 1,91 & 3 & 8,424 & 0,000 \\
$4^{\text {th }}$ & 56 & 1,87 & & & \\
In total & 220 & 1,88 & & & \\
\hline
\end{tabular}

We also examined the difference between two individual grades with an LSD-test. Results can be seen in Table 6 . They show that there is a statistically significant difference only between the $1^{\text {st }}$ and the $2^{\text {nd }}$ grade $(p=0,000)$, and between the $1^{\text {st }}$ and the $3^{\text {rd }}$ grade $(p=0,004)$. On the other hand, there is no statistically significant difference between the $1^{\text {st }}$ and the $4^{\text {th }}$ grade $(\mathrm{p}=0,011), 2^{\text {nd }}$ and the $3^{\text {rd }}$ grade $(\mathrm{p}$ $=0,029), 2^{\text {nd }}$ and the $4^{\text {th }}$ grade $(\mathrm{p}=0,013)$, or the $3^{\text {rd }}$ and the $4^{\text {th }}$ grade $(p=0,739)$.

Table 6. LSD-test - difference in physical functioning between grades

\begin{tabular}{cc}
\hline Compared grades & $\mathrm{p}$ \\
\hline $1^{\text {st }}$ and $2^{\text {nd }}$ & 0,000 \\
$1^{\text {st }}$ and $3^{\text {rd }}$ & 0,004 \\
$1^{\text {st }}$ and $4^{\text {th }}$ & 0,011 \\
$2^{\text {nd }}$ and $3^{\text {rd }}$ & 0,029 \\
$2^{\text {nd }}$ and $4^{\text {th }}$ & 0,013 \\
$3^{\text {rd }}$ and $4^{\text {th }}$ & 0,739 \\
\hline
\end{tabular}

Table 7 shows physical functioning of students in relation to gender, and we can see that there is a statistically significant difference $(p=0,000)$ between male and female students.
Table 7. Physical functioning in relation to gender

\begin{tabular}{ccccccc}
\hline Gender & $\mathrm{N}$ & Mean & Std. Deviation & $\mathrm{t}$ & $\mathrm{df}$ & $\mathrm{p}$ \\
\hline Male & 100 & 1,66 & 0,52 & & & \\
Female & 120 & 2,07 & 0,56 & 5,438 & 218 & 0,000 \\
\hline
\end{tabular}

We also wanted to know whether there are differences in physical functioning with regard to students' place of residence. The results can be seen in Table 8 and they show that there is no statistically significant difference in physical functioning between students who live in urban and rural areas $(p=0,149)$.

Table 8. Physical functioning in relation to place of residence

\begin{tabular}{ccccccc}
\hline $\begin{array}{c}\text { Type of } \\
\text { settlement }\end{array}$ & $\mathrm{N}$ & Mean & $\begin{array}{c}\text { Std. } \\
\text { Deviation }\end{array}$ & $\mathrm{t}$ & $\mathrm{df}$ & $\mathrm{p}$ \\
\hline City & 138 & 1,84 & 0,55 & 1,447 & 218 & 0,149 \\
Village & 82 & 1,96 & 0,61 & & & \\
\hline
\end{tabular}

We used a scale of emotional functioning with 5 questions in the research. Responses are ranked from 1 to 5 , and the results can be seen in Table 9.

The first item on the scale is one in which students state whether they feel fear or not, with 2.34 points. Most students said they occasionally feel fear (39.1\%), almost never feel fear $(30.0 \%)$ and never feel fear $(22.7 \%)$. The second item was ranked with 2.38 points. Students' responses to the statement "I have troubles sleeping" were the following - never $(32.7 \%)$ and almost never $(26.4 \%)$. The ranking of the third item referring to one emotion, sadness, was 2.65 points. The greatest percent of students said they feel sad sometimes (46.6\%). A similar percent of students feel anger sometimes (42.7\%), which is shown by the fourth item, with 2.75 points on the scale. The fifth item got 2.88 points, so $20.0 \%$ of respondents never worry about what will happen to them, $17.3 \%$ almost never worry, $29.1 \%$ worry sometimes, whereas others are often worried $(21.8 \%)$ or almost always (11.8\%). The average ranking on the emotional functioning scale is 2.6 . 
Table 9. Scale of emotional functioning

\begin{tabular}{|c|c|c|c|c|c|c|}
\hline Item & Never & Almost never & Sometimes & Often & Almost always & Ranking \\
\hline \multirow{2}{*}{ I feel fear. } & 50 & 66 & 86 & 16 & 2 & \multirow{2}{*}{2,34} \\
\hline & $22,7 \%$ & $30,0 \%$ & $39,1 \%$ & $7,3 \%$ & $0,9 \%$ & \\
\hline \multirow{2}{*}{ I have trouble sleeping. } & 72 & 58 & 38 & 38 & 14 & \multirow{2}{*}{2,38} \\
\hline & $32,7 \%$ & $26,4 \%$ & $17,3 \%$ & $17,3 \%$ & $6,4 \%$ & \\
\hline \multirow{2}{*}{ I feel sad. } & 14 & 78 & 102 & 22 & 4 & \multirow{2}{*}{2,65} \\
\hline & $6,4 \%$ & $35,5 \%$ & $46,4 \%$ & $10,0 \%$ & $1,8 \%$ & \\
\hline \multirow{2}{*}{ I feel angry. } & 22 & 62 & 94 & 34 & 8 & \multirow{2}{*}{2,75} \\
\hline & $10,0 \%$ & $28,2 \%$ & $42,7 \%$ & $15,5 \%$ & $3,6 \%$ & \\
\hline \multirow{2}{*}{ I worry what will happen to me. } & 44 & 38 & 64 & 48 & 26 & \multirow{2}{*}{2,88} \\
\hline & $20,0 \%$ & $17,3 \%$ & $29,1 \%$ & $21,8 \%$ & $11,8 \%$ & \\
\hline
\end{tabular}

We also examined whether there are differences in emotional functioning in relation to respondents' grade, which is shown in Table 10. Differences in attitudes between different grades were examined with a t-test. The table shows that there is a statistically significant difference between grades $(\mathrm{p}=0,002)$.

Table 10. Emotional functioning in relation to grade

\begin{tabular}{cccccc}
\hline Grade & $\mathrm{N}$ & Mean & df & F & p \\
\hline $1^{\text {st }}$ & 52 & 2,46 & & & \\
$2^{\text {nd }}$ & 54 & 2,68 & & & \\
$3^{\text {rd }}$ & 58 & 2,79 & 3 & 4,999 & 0,002 \\
$4^{\text {th }}$ & 56 & 2,45 & & & \\
In total & 220 & 2,60 & & & \\
\hline
\end{tabular}

It was important to determine whether there are differences in emotional functioning between two different grades and results can be seen in Table 11. We used an LSD-test to examine the difference between pairs of grades. The results show that there is a statistically significant difference between the $1^{\text {st }}$ and the $3^{\text {rd }}$ grade $(p=0,002)$ and between the $3^{\text {rd }}$ and the $4^{\text {th }}$ grade $(\mathrm{p}=0,001)$. Results also show that there is no statistically significant difference between the $1^{\text {st }}$ and the $2^{\text {nd }}$ grade $(\mathrm{p}=0,46)$, between the $1^{\text {st }}$ and the $4^{\text {th }}(\mathrm{p}=0,916)$, between the $2^{\text {nd }}$ and the $3^{\text {rd }}$ grade $(\mathrm{p}$ $=0,297)$ or between the $2^{\text {nd }}$ and the $4^{\text {th }}$ grade $(p=0,033)$.

Table 11. LSD-test - difference between emotional functioning between grades

\begin{tabular}{cc}
\hline Compared grades & $\mathrm{p}$ \\
\hline $1^{\text {st }}$ and $2^{\text {nd }}$ & 0,046 \\
$1^{\text {st }}$ and $3^{\text {rd }}$ & 0,002 \\
$1^{\text {st }}$ and $4^{\text {th }}$ & 0,916 \\
$2^{\text {nd }}$ and $3^{\text {rd }}$ & 0,297 \\
$2^{\text {nd }}$ and $4^{\text {th }}$ & 0,033 \\
$3^{\text {rd }}$ and $4^{\text {th }}$ & 0,001 \\
\hline
\end{tabular}

Table 12 shows differences in emotional functioning with regard to gender. Results of the research show that there is a statistically significant different $(p=0,000)$ in emotional functioning between male and female students.

Table 12. Emotional functioning in relation to gender

\begin{tabular}{ccccccc}
\hline Gender & $\mathrm{N}$ & Mean & Std. Deviation & $\mathrm{t}$ & $\mathrm{df}$ & $\mathrm{p}$ \\
\hline Male & 100 & 2,42 & 0,612 & & & \\
Female & 120 & 2,75 & 0,506 & 4,375 & 218 & 0,000 \\
\hline
\end{tabular}

Our research also examined whether there are any differences between students in relation to their place of residence, which is shown in Table 13. Results show that there is no statistically significant difference in emotional functioning between students who live in an urban environment and those who live in a rural environment $(\mathrm{p}=$ $0,179)$.

Table 13. Emotional functioning in relation to place of residence

\begin{tabular}{ccccccc}
\hline $\begin{array}{c}\text { Type of } \\
\text { settlement }\end{array}$ & $\mathrm{N}$ & Mean & $\begin{array}{c}\text { Std. } \\
\text { Deviation }\end{array}$ & $\mathrm{t}$ & $\mathrm{df}$ & $\mathrm{p}$ \\
\hline City & 138 & 2,64 & 0,601 & & & \\
Village & 82 & 2,53 & 0,538 & 1,349 & 218 & 0,179 \\
\hline
\end{tabular}

The scale of social functioning has 5 questions and responses are ranked from 1 to 5 . Responses can be seen in Table 14.

The first item refers to playing with other children, with 1.18 points on the scale. The largest percent of students stated that they never have trouble keeping up with other children while playing $(88.2 \%)$. The second item is the statement "I cannot do things other children can", with 1.43 points on the scale. Most students responded never (68.2\%) or almost never $(21.8 \%)$ to this statement. The third item was awarded 1.53 points on the scale. Most students responded with never $(66.4 \%)$ or almost never $(23.6 \%)$ to the statement that other children don't want to socialise with them. Response distribution is slightly different when it comes to the fourth item, with 1.56 points on the scale, because $62.7 \%$ students responded with never, $20.9 \%$ almost never and $14.5 \%$ sometimes. The fifth item referred to how a respondent gets along with other students. Around a half of students $(54.5 \%)$ answered with never, and (33.6\%) said almost never. The average ranking on the social functioning scale is 1.46 points. 
Table 14. Scale of social functioning

\begin{tabular}{|c|c|c|c|c|c|c|}
\hline Item & Never & Almost never & Sometimes & Often & Almost always & Ranking \\
\hline \multirow{2}{*}{$\begin{array}{l}\text { I have trouble keeping up with other } \\
\text { children while playing. }\end{array}$} & 194 & 18 & 4 & 2 & 2 & \multirow{2}{*}{1,18} \\
\hline & $88,2 \%$ & $8,2 \%$ & $1,8 \%$ & $0,9 \%$ & $0,9 \%$ & \\
\hline \multirow{2}{*}{ I cannot do things other children can. } & 150 & 48 & 20 & 2 & 0 & \multirow{2}{*}{1,43} \\
\hline & $68,2 \%$ & $21,8 \%$ & $9,1 \%$ & $0,9 \%$ & $0,0 \%$ & \\
\hline \multirow{2}{*}{$\begin{array}{l}\text { Other children don't want to socialise } \\
\text { with me. }\end{array}$} & 146 & 52 & 8 & 8 & 6 & \multirow{2}{*}{1,53} \\
\hline & $66,4 \%$ & $23,6 \%$ & $3,6 \%$ & $3,6 \%$ & $2,7 \%$ & \\
\hline \multirow{2}{*}{ I get teased by other children. } & 138 & 46 & 32 & 2 & 2 & \multirow{2}{*}{1,56} \\
\hline & $62,7 \%$ & $20,9 \%$ & $14,5 \%$ & $0,9 \%$ & $0,9 \%$ & \\
\hline \multirow{2}{*}{ I don't get along with other children. } & 120 & 74 & 20 & 0 & 6 & \multirow{2}{*}{1,63} \\
\hline & $54,5 \%$ & $33,6 \%$ & $9,1 \%$ & $0,0 \%$ & $2,7 \%$ & \\
\hline
\end{tabular}

It was important to determine whether there are differences in social functioning in relation to respondents' grade, which is shown in Table 15. We used a t-test to examine the differences in attitudes between grades. The table shows that there is no statistically significant difference between grades $(p=0,059)$.

Table 15. Social functioning in relation to grade

\begin{tabular}{cccccc}
\hline Grade & $\mathrm{N}$ & Mean & $\mathrm{df}$ & $\mathrm{F}$ & $\mathrm{p}$ \\
\hline $1^{\text {st }}$ & 52 & 7,11 & & & \\
$2^{\text {nd }}$ & 54 & 7,48 & & & \\
$3^{\text {rd }}$ & 58 & 6,72 & 3 & 2,513 & 0,059 \\
$4^{\text {th }}$ & 56 & 8,00 & & & \\
In total & 220 & 7,33 & & & \\
\hline
\end{tabular}

We also examined the differences in social functioning between individual grades with an LSD-test. The results are shown in Table 16. Results show that there is a statistically significant difference between the following grades: the $1^{\text {st }}$ and the $2^{\text {nd }}$ grade $(\mathrm{p}=0,465)$, and the $1^{\text {st }}$ and the $3 r d(p=0,427)$, whereas there is no statistically significant difference between the $1^{\text {st }}$ and $4^{\text {th }}$ grade $(\mathrm{p}=$ $0,076)$, the $2^{\text {nd }}$ and the $3^{\text {rd }}$ grade $(p=0,122)$, the $2^{\text {nd }}$ and the $4^{\text {th }}$ grade $(\mathrm{p}=0,293)$ and the $3^{\text {rd }}$ and the $4^{\text {th }}$ grade $(p=$ $0,009)$.

Table 16. LSD-test - difference in social functioning between grades

\begin{tabular}{cc}
\hline Compared grades & $\mathrm{p}$ \\
\hline $1^{\text {st }}$ and $2^{\text {nd }}$ & 0,465 \\
$1^{\text {st }}$ and $3^{\text {rd }}$ & 0,427 \\
$1^{\text {st }}$ and $4^{\text {th }}$ & 0,076 \\
$2^{\text {nd }}$ and $3^{\text {rd }}$ & 0,122 \\
$2^{\text {nd }}$ and $4^{\text {th }}$ & 0,293 \\
$3^{\text {rd }}$ and $4^{\text {th }}$ & 0,009 \\
\hline
\end{tabular}

Table 17 shows differences in social functioning with regard to gender. Results show that there is a statistically significant difference $(p=0,005)$ in social functioning between male and female respondents.

Table 17. Social functioning in relation to gender

\begin{tabular}{ccccccc}
\hline Gender & $\mathrm{N}$ & Mean & Std. Deviation & $\mathrm{t}$ & $\mathrm{df}$ & $\mathrm{p}$ \\
\hline Male & 100 & 1,57 & 0,617 & & & \\
Female & 120 & 1,37 & 0,405 & & 218 & 0,005 \\
\hline
\end{tabular}

The research examined whether there are differences in social functioning in relation to students' place of residence, which is shown in Table 18. Research results show that there is no statistically significant difference in social functioning between students who live in an urban environment and those who live in a rural environment $(\mathrm{p}=$ $0,119)$.

Table 18. Social functioning in relation to place of residence

\begin{tabular}{ccccccc}
\hline $\begin{array}{c}\text { Type of } \\
\text { settlement }\end{array}$ & $\mathrm{N}$ & Mean & $\begin{array}{c}\text { Std. } \\
\text { Deviation }\end{array}$ & $\mathrm{t}$ & $\mathrm{df}$ & $\mathrm{p}$ \\
\hline City & 138 & 1,42 & 0,516 & 1,567 & 218 & 0,119 \\
Village & 82 & 1,53 & 0,523 & & & \\
\hline
\end{tabular}

We used factor analysis (oblimin rotation) to single out six relatively independent factors that determine students' quality of life. These six factors explain $62.01 \%$ of the total variance.

Factor 1 - This factor refers to physical activities and explains $19.97 \%$ of the total variance. It comprises the following attitudes:

1. It is hard for me to run. (participation coefficient: 0,886 )

2. It is hard for me to play sports or engage in any form of exercise. (participation coefficient: 0,792 )

3. It is hard for me to walk more than several streets. (participation coefficient: 0,632 )

Examined students commonly don't find it hard to participate in functional and sports activities. Several physical activities were singled out, from the simplest to the most complex ones. Hiking, which can be a daily necessity, is one of the activities students categorised as easy. Students don't have troubles walking or hiking more than several streets. Running is also not an effort for most students. The most complex physical activities, such as exercises or sports, commonly do not represent a major effort for students.

Factor 2 - This factor refers to peer integration and relationships with other children. It explains $12.13 \%$ of the total variance and comprises the following attitudes:

1. Other children don't want to socialise with me. (participation coefficient: 0,849 )

2. I get teased by other children. (participation 
coefficient: 0,693)

3. I cannot do things other children can. (participation coefficient: 0,548 )

4. I don't get along with other children. (participation coefficient: 0,515 )

5. I have trouble keeping up with other children while playing. (participation coefficient: 0,508 )

6. It is hard for me to do any heavy lifting. (participation coefficient: 0,389 )

The social aspects of students' life help them establish communication with their peers and develop mutual relationships. Thus, students singled out the contribution of peer integration and relationships with other children as significant for their quality of life. At this age, students are particularly influenced by their peers; they compare and identify with them, and influence each other through mutual interaction. In addition, peer integration is very significant and it is reflected in the acceptance, understanding, support and companionship with one's peers. Good relationships with peers help improve students' quality of life.

Factor 3 - This factor refers to health and individual activity. It explains $9.02 \%$ of the total variance and it comprises the following attitudes:

1. It is hard for me to do housework. (participation coefficient: 0,723 )

2. It is hard for me to take showers or baths. (participation coefficient: 0,630 )

3. I experience pain. (participation coefficient: $0,615)$

Students are aware that health is very important for one's quality of life, and single out hygiene, both personal and the hygiene of their home, as important components. It is especially important that students have categorised personal hygiene as an element that improves quality of life. In addition, students commonly don't see housework as an effort, which is a sign that they understand that keeping one's home tidy is both a need and a duty.

Factor 4 - This factor refers to emotions and physical activity. It explains $7.80 \%$ of the total variance and comprises the following attitudes:

1. I have troubles sleeping. (participation coefficient: 0,698 )

2. I don't have enough strength. (participation coefficient: 0,675 )

Quality of life of students at this age begins with the emotional sphere related to activity. Connecting physical activity and rest provides satisfaction in everyday activities. In addition, students also associate quality of life with having enough strength to perform daily activities.

Factor 5 - This factor refers to the fear of uncertainty. It explains $6.85 \%$ of the total variance and comprises the following attitudes:

1. I worry what will happen to me. (participation coefficient: 0,730 )

\section{I feel fear. (participation coefficient: 0,703)}

One of the factors that stand out is the factor referring to students' emotions, anxiety and fear. The fear of uncertainty is present as a factor that affects the quality of life, because this anxiety greatly influences one's life.

Factor 6 - This factor refers to emotional sincerity through emotional expression. It explains $6.21 \%$ of the total variance and it comprises the following attitudes:

1. I feel angry (participation coefficient: 0,725 )

2. I feel sad (participation coefficient: 0,415)

Students' emotions influence the quality of their life, and especially if they are sincerely expressed. Thus, students have singled out emotions that have the greatest influence on their life, sadness and anger.

\section{Results, Conclusions and Recommendations}

The importance of this research lies in the fact that quality of life should be understood as a platform of lifelong education. It provides opportunities for acquiring quality and efficient education throughout one's life.

Research results indicate that the average ranking on the scale of physical functioning is 1,88 , which tells us that most student responses are grouped around the $2^{\text {nd }}$ point on the scale, expressing the attitude - almost never, the average ranking on the scale of emotional functioning is 2,6 , whereas the average ranking on the scale of social functioning equals 1,46 . In other words, students assessed the quality of their life in terms of emotional, physical and social functioning as very high.

Based on the research, we observed that, when it comes to physical functioning, there is a statistically significant difference between grades $(p=0,000)$; that there is a statistically significant difference in emotional functioning between grades $(p=0,002)$, whereas there is no statistically significant difference in social functioning between grades $(p=0,059)$. When it comes to students of senior grades, they have higher rankings on the scale in comparison to younger students.

Research results further show that there is a statistically significant difference $(p=0,000)$ between male and female students (physical functioning); there is also a statistically significant difference in emotional functioning $(p=0,000)$ between male and female students, and finally, there is a statistically significant difference in social functioning $(\mathrm{p}=$ 0,005 ) between male and female respondents. When it comes to physical and emotional functioning, male students had higher rankings, whereas female students had higher rankings on the scale of social functioning.

Results show that there is no statistically significant difference in physical functioning with regard to students' place of residence $(p=0,149)$, nor in emotional $(p=0,179)$, and social functioning $(\mathrm{p}=0,119)$ between students who 
live in urban and those who live in rural environments. When it comes to emotional functioning, students from rural environments had higher rankings on the scale, whereas students from urban environments had higher rankings on the scale of social and physical functioning.

We used factor analysis (oblimin rotation) to single out six relatively independent factors that determine the quality of life of our respondents: Factor 1 - Physical activity (19.97\% of the total variance); Factor 2 - Peer integration and relationships with other children $(12.13 \%$ of the total variance); Factor 3 - Health and individual activity $(9.02 \%$ of the total variance); Factor 4 - Emotions and physical activity $(7.80 \%$ of the total variance); Factor $5-$ Fear of uncertainty $(6.85 \%$ of the total variance) and Factor $6-$ Emotional sincerity through emotional expression $(6.21 \%$ of the total variance).

Examined students commonly don't find it hard to participate in functional and sports activities. Several physical activities were singled out, from the simplest to the most complex ones. The social aspects of students' life help them establish communication with their peers and develop mutual relationships. Thus, students singled out the contribution of peer integration and relationships with other children as significant for their quality of life. Students are aware than health is very important for one's quality of life, and singled out hygiene, both personal and the hygiene of their home, as important components. Quality of life of students at this age begins with the emotional sphere related to activity. Connecting physical activity and rest provides satisfaction in everyday activities. In addition, students also associate quality of life with having enough strength to perform daily activities. One of the factors that stand out is the factor referring to students' emotions, anxiety and fear. The fear of uncertainty is present as a factor that affects the quality of life, because this anxiety greatly influences one's life. Students' emotions influence the quality of their life, and especially if we they are sincerely expressed. Thus, students have singled out emotions that have the greatest influence on their life, sadness and anger.

One of the most important indicators of quality of life is education. However, we should mention a paradox here. Namely, it often occurs that systematically acquired knowledge and skills from the domain of education quality (Ефимова, 2011) are impossible to implement (or can be implement to a lesser extent) in professional activities, which directly affects quality of one's life and consequently, quality of lifelong education. In the environment of insufficiently developed economy and high unemployment, a lack of opportunities (interest, motivation) for knowledge implementation (Шорохова, 2014) inevitably leads to deterioration of certain aspects of the individual's quality of life, so the question is: How can young and educated people obtain continuous lifelong education?

Therefore, improving quality of life requires the detection and elimination of all those factors that negatively affect the individual's quality of life, and reinforcing protective factors which directly or indirectly improve lifelong education.

\section{Recommendations}

- Activating processes (programs) that will improve an individual's physical, emotional and social functioning.

- Aspects mentioned in this research (and all others omitted from it) should be thoroughly analysed and strategies for improving quality of life as a platform for lifelong education should be created.

- Working on new concepts of organisational policy to mitigate or eliminate critical points that negatively influence the efficiency of lifelong education.

\section{REFERENCES}

[1] Arsovski, S. (2007). Merenje, vrednovanje i praćenje kvaliteta života. Festival kvaliteta 2007, 2. Nacionalna konferencija o kvalitetu života. Kragujevac, 8-11. maj 2007, Asocijacija za kvalitet i standardizaciju Srbije. http://www.cqm.rs/2007/2.html.

[2] Assunção, A. Á., Olıveıra, D. A. (2009). Intensificação do trabalho e saúde dos professores. Educação \& Sociedade, Campinas, 30(107), 349-372. http://www.scielo.br/pdf/es/v30n107/03.pdf. Downloaded: November 20, 2011.

[3] Chravenato, I. (2009). Recursos humanos: o capital humano das organizações. 9 ed. Rio de Janeiro: Elsevier.

[4] Damnjanović, M. (2012). Karakteristike kvaliteta života i mentalnog zdravlja dece i adolescenata koji su u sistemu socijalne zaštite. Doktorska disertacija. Beograd: Univerzitet u Beogradu-Medicinski fakultet.

[5] Ефимова, И. А. (2011). Повышение качества высшего образования в российской Федерации / и. А. ефимова // креативная экономика. - № 5. - Вып. 1 (183). - C. 151-154.

[6] Fayers, P. M., Machin D. (2007). Quality of Life: The assessment, analysis and interpretation of patient-reported outcomes. 2nd ed. Chichester: John Wiley \& Sons.

[7] Guyatt, G., Feeny, D., Patrick, D. (1991). Issues of quality-of-life measurement in clinical trials. Control Clin Trials 1991, 12:S, 81-90.

[8] Jovanović, M. (2013). Socijalni aspektkvaliteta života osoba sa telesnim invaliditetom. Ruma, Beograd: Gradska biblioteka, Anastasija Stojković”, EDICIJA Posebna izdanja.

[9] Limong1-França, A. C. (2007). Qualidade de vida no trabalho - Q.V.T. Conceitos e práticas nas empresas da sociedade pósindustrial. São Paulo: Atlas. 
[10] Limong1-França, A. C. (2012). Qualidade de Vida no Trabalho - Q.V.T. Conceitos e práticas nas empresas da sociedade pósindustrial. $2^{\mathrm{a}}$ ed. São Paulo: Atlas.

[11] Marić, M. (2012). Permanentno obrazovanje, opšte zadovoljstvo životom i psihičko blagostanje, Andragoške studije, 1, 81-98.

[12] Milošević, L. (2009). Obrazovanje za treće doba u funkciji očuvanja i unapređenja kvaliteta života u starosti. Godišnjak za sociologiju, 5, 207-217.

[13] Murphy, B., Herrman, H., Hawthorne, G., Pinzone, T., Evert, H. (2000). Australian WHOQOL instruments: User's manual and interpretation guide. Melbourne: Australian WHOQOL Field Study Centre.

[14] Ryff, C. D., Magee, W. J., Kling, K. C., \& Wing, E. H. (1999). Forging macro-micro linkages in the study of psychological well-being. In C. D. Ryff \& V. W. Marshall (Eds.). The self and society in aging processes, 247-278, New York: Springer.

[15] Slavnic S., Kovachevic, J., Radovanovic V., Jachova, Z. (2015). The quality of life of deaf and hard of hearing students in boarding schools. 6th International conference "Improving the quality of life of children and young people”, 569-579, Ohrid, 2015.

http://www.erf.untz.ba/aktuelnosti/poziv.pdf

[16] The WHOQOL Group. (1998). WHOQOL User manual. Geneva: WHO.

[17] Шорохова, М. А. (2014). Диалектический подход к проблеме качества жизни / М. А. Шорохова, и. л. Сиротина // известия высших учебных заведений. Поволжский регион. Гуманитарные науки. - № 2 (30). - С. 70-77. 